PUPIL: International Journal of Teaching, Education and Learning

ISSN 2457-0648

Samuel Oppong Frimpong, 2021

Volume 5 Issue 3, pp. 21-36

Received: $3^{\text {rd }}$ February 2021

Revised: 12 th August 2021, 12 ${ }^{\text {th }}$ October 2021

Accepted: $9^{\text {th }}$ November 2021

Date of Publication: 22 ${ }^{\text {nd }}$ November 2021

DOI- https://doi.org/10.20319/pijtel.2021.53.2136

This paper can be cited as: Oppong Frimpong, S. (2021). Interaction, The Pivot around which Quality Early Childhood Education Should Revolve. PUPIL: International Journal of Teaching, Education and Learning, 5(3), 21-36.

This work is licensed under the CreativeCommons Attribution-NonCommercial 4.0 International License. To view a copy of this license, visit http://creativecommons.org/licenses/by-nc/4.0/ or send a letter to Creative Commons, PO Box 1866, Mountain View, CA 94042, USA.

\title{
INTERACTION, THE PIVOT AROUND WHICH QUALITY EARLY CHILDHOOD EDUCATION SHOULD REVOLVE
}

\author{
Samuel Oppong Frimpong \\ $\mathrm{PhD}$, Department of Early Childhood Education, University of Education, Winneba, Ghana \\ sofrimpong@uew.edu.gh
}

\begin{abstract}
This position paper advocates that the extent to which children are involved in the teaching and learning process and their environment determines how much knowledge they can create for themselves. The nature of children's involvement in teaching and learning is largely couched in interaction. Where meaningful involvement in teaching and learning is achieved, it symbolizes quality teaching and learning. Thus, the most important ingredient in Quality Early Childhood Education (QECE) provision is interaction, referring to the contact between two or more people or a person and an object over a common interest. Interaction being argued to be the means by which an early childhood centre functions on a daily basis, the quality of interaction and instruction young children receive at the ECE centres can make or unmake their later lives. Thus, with interaction in the school, learners can have contact with their peers, manipulate TLMs, participate actively during lesson delivery, and take an active part in every activity. Quality interaction, therefore, shows the extent to which learners can be involved in the content of what they are learning both indoor and outdoor within their environment. Consequently, rich interactive experiences at ECE centre play a key role in children's optimal development.
\end{abstract}


PUPIL: International Journal of Teaching, Education and Learning

ISSN 2457-0648

\section{Keywords}

Interaction, Pivot, Quality, Early Childhood Education

\section{Introduction}

In spite of the importance a wealth of research has attached to Quality Early Childhood Education (QECE) provision as ensuring the optimal development of the individual who goes through it (Sylva, Melhuish, Sammons, Siraj-Blatchford \& Taggart, 2011 \& 2004; Schweinhart, Barnes \& Weikart, 2005; Lowenstein, 2011), quality ECE cannot be achieved without it being anchored in quality interaction (e.g., Early, Maxwell, Burchinal, Alva, Bender \& Bryant, 2007).

\subsection{Dimensions of Quality Early Childhood Education}

There are three main dimensions to the provision of early childhood education. Thus, the structural dimension, process dimension, and product dimension. It is important to note however that it is the structural and the process dimensions that give rise to the product dimension. In other words, how the structural and the process dimensions are appropriately combined in the provision of early childhood education determines the kind of outcome for such provision. Figure 1 gives a pictorial view of the dimensions.

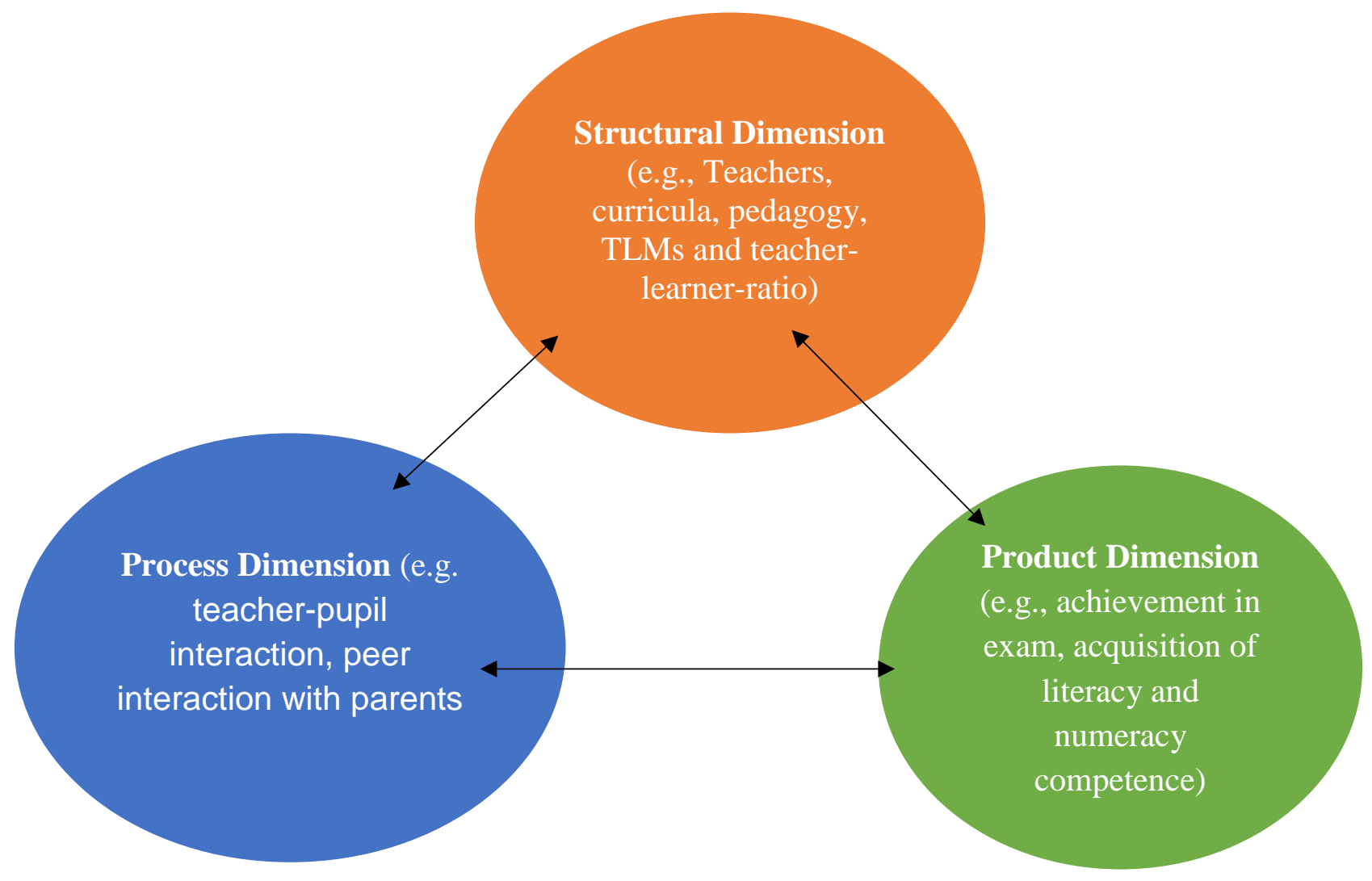

Figure 1: Dimensions of QECE Provision 
The structural dimension of quality is concerned with aspects of educational programmes like the physical environments, curricula, teacher qualifications, specialised training and experience, teacher-pupil ratios, class size, space requirement, and length of the programme (Vandell, 2004; Mooney, 2007; Pianta, Barnett, Burchinal \& Thornburg, 2009). Structural features are elements invested into education; they are relatively durable, do not easily change their nature, and are considered necessary for creating a QECE classroom (Mooney, 2007). As far as Ghana is concerned, the structural features are made of educational personnel (e.g., teachers, their training, availability), pedagogical and content knowledge (i.e. the relevance and volume of the curricula and TLMs). Others are educational facilities (e.g., classrooms, tables, and chairs) and finance (i.e., monies made available for the purposes of education) (Ankomah Koomson, Bosu \& Oduro (2005). According to Pianta et al. (2009), the provision of structural features alone may not automatically guarantee that children will receive a quality education. In other words, they are necessary but not sufficient conditions for QECE.

The process dimension denotes the functioning of an early childhood centre on a daily basis and in particular, the interaction that takes place there. This includes teacher-pupil interaction, peer interaction, teacher-family interaction, and teaching or pedagogical quality (Pianta et al., 2009; Lowenstein, 2011). Mashburn, Pianta, Hamre, Downer, Barbarin \& Bryant (2008) suggest that process variables, in the form of this interaction, are the most important factors in providing QECE, and Gilliam (2009) states that they are the real variables underpinning QECE because they involve the day-to-day activities of an ECE centre. Although three dimensions have been identified as constituting and contributing to QECE in this discussion (i.e., structural, process and product), the emphasis is, however, on the process dimension.

\subsection{Motivation for this Position Paper}

As presented in Section 1.1, the researcher takes a position in favour of the process dimension and argues that QECE should be anchored on it. The motivation for my position stems from the fact that the structural dimension is necessary to set the stage for QECE provision but is not sufficient in itself. It is a necessary means to an end and not sufficient in itself. The process dimension translates structural features into QECE provision. Thus, one would have expected that the centrality of the process dimension would have been acknowledged as such, attention would be paid to it and therefore more research would have been done into how it can properly be organised to ensure QECE.

Nevertheless, concerns about the quality of ECE provision in Ghana revolve around the structural dimension of quality. The concentration of ECE provision in Ghana around the structural dimension of quality appears to be problematic. Cobbold (2006) and Torrente et al. (2015) argue in favour of the centrality of quality involvement in achieving QECE. Ngware, Oketch \& Mutisya 
(2014) note how it is often relegated to the background in terms of research and people's perception of its contribution to QECE in Ghana and in Sub-Saharan African (SSA). The researcher's own interaction with some key stakeholders (teachers and headteachers), personal observation through visits to some ECE centres and reading of the literature available to the researcher on the process dimension appear to support the inadequate attention given to it and the neglect of the centrality of the process dimension which is the quality of interaction that should take please on daily basis at the ECE centres. Consequently, this position paper focuses on what goes on at the ECE centre and this closely aligns with the process dimension of quality with particular emphasis on interaction and how it brings about QECE.

\section{Interaction Defined}

Oppong Frimpong (2017, p. 42) conceptualised interaction as "the contact (coming together) between two or more people or a person and an object over a common interest, which could be sharing information, giving assistance and/or learning". In an ECE setting, therefore, the contact can be between the teacher and learners, teachers and headteachers, among teachers, among learners, and between learners and TLMs and play items. From the conceptualisation, the interaction involves, firstly, contact; secondly, a purpose for the contact; and thirdly, a mutual or common interest shared by the parties involved. Although TLMs are inanimate objects and so cannot declare their common interest, I maintain that, as the name TLM suggests, these teaching aids are made with the intent of helping teachers' teaching and the learners' learning. Therefore, they share an interest in making possible and easy the provision of QECE.

\subsection{Conceptualisation of Interaction}

Interaction in ECE can be organized into three categories (i.e. interaction between teacherlearner, learner-learner, and learner-content [Murphy, Casey \& Fraser, 2007]). Figure 2 presents a brief dramatic description of the categories involved in interaction and examples of each of them.

Potentially, there cannot be any meaningful interaction in the school without quality interaction between teacher-learner, learner-learner, and learner-content. The quality of interaction between the teacher and the learner primarily involves their daily exchanges throughout the school day. This may be through indoor or outdoor activities. It can be in the form of communication (oral or gestures) and include how teachers respond to children's questions during classroom teaching and outside classroom activities and how responsive teachers are to their children's needs. Equally, it encompasses the opportunities teachers create to relate to their children during teaching and learning and how the infrastructure, TLMs, and play equipment afford teachers the opportunity to involve children as they learn (Hamre \& Pianta, 2007; Wang, 2013). 


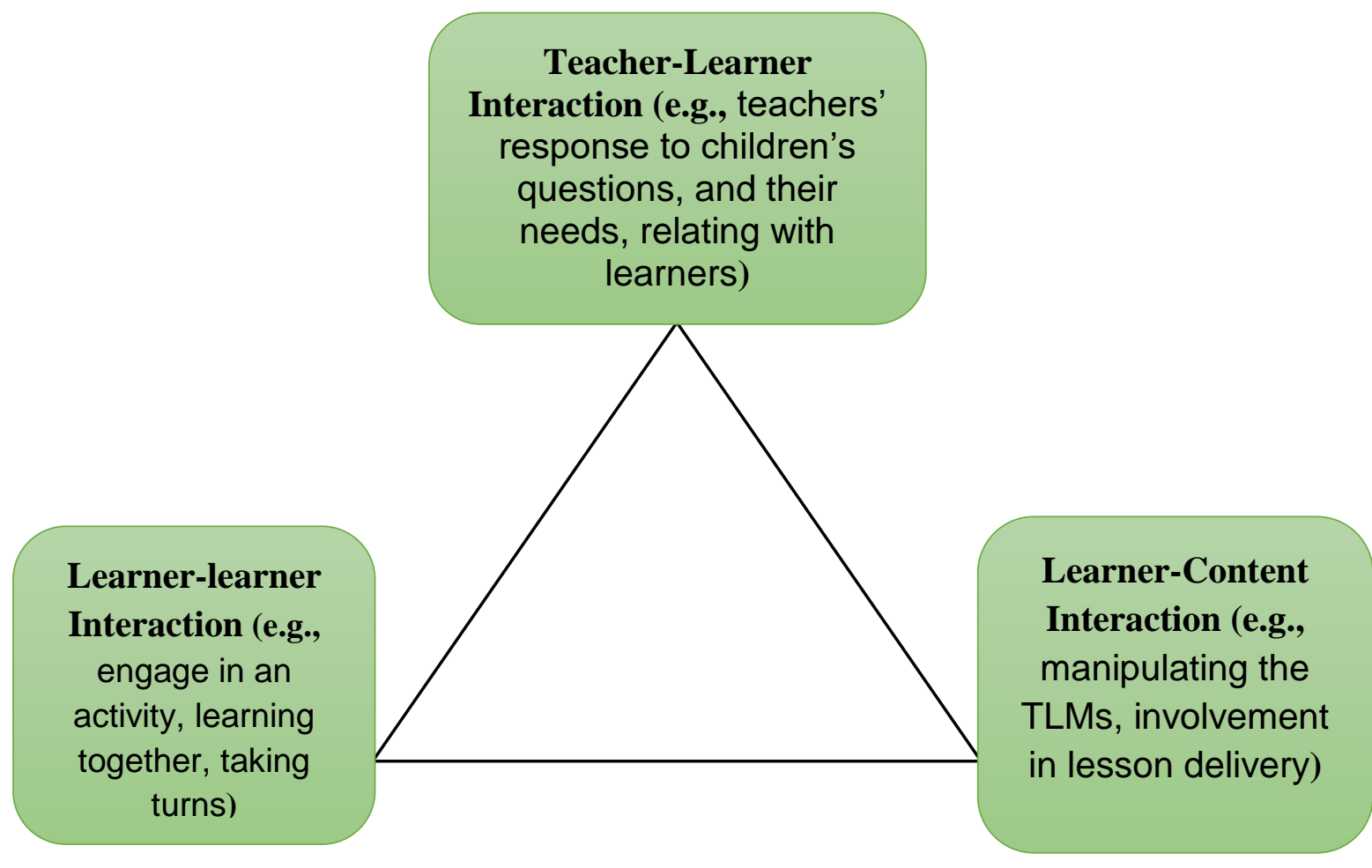

Figure 2: Categories of Interaction

The quality of the interaction between the learner and the content or subject of study involves the learner encountering the content of the study, manipulating the TLMs, associating with the environment, and being involved in the lesson being delivered. It results in changes in the learner's cognitive structures including his/her understanding of what is being taught. Moore (1989) argues that, since the learner's interaction with the subject of study is what brings about change in the learner's understanding, there cannot be education without quality learner-content interaction. Interaction between learners is when learners come together to engage in an activity. It can be in the form of children learning or playing together, taking turns during play, giving and receiving assistance from each other, and learning to share among themselves (Cadima, Leal, \& Burchinal, 2010).

From the discussion of the definition of interaction, it can be inferred that the learner has the opportunity to involve him/herself in the teaching and learning process through contact with his/her teacher, peers, and/or TLMs and the environment. The quality of these opportunities is what facilitates learning and therefore determines quality at the early childhood centre. Now it is important to take a look at what quality ECE is, what is Ghana's perspective on what quality early childhood education is, and how interaction brings about quality early childhood education provision.

\subsection{What is ECE and QECE provision}

UNESCO (2010) considers ECE to be the education of young children that promotes their physical well-being, cognitive and linguistic skills, and social and emotional maturity. Accordingly, 
ECE covers the period from birth to age eight and encompasses education, health, nutrition, and protection services (UNESCO, 2010). It also incorporates care, which is centered on the creation of an environment that is favourable to the total development of a child. The MWCA in Ghana defines ECE as the timely provision of a range of services that promote the survival, growth, development, and protection of a young child (MWCA, 2004).

Oppong Frimpong (2019) defines ECE as the educational provision aimed at meeting the academic, health, nutritional and psycho-social needs of children between 0 and 6 years old in an interactive environment conducive to their optimal development. A conducive interactive environment includes developmentally appropriate curricula, specially trained teachers, childfriendly materials, interactive pedagogy, cordial relationships, and safe and secure infrastructure. Optimal development refers to the skills and competencies a child will acquire from experiencing ECE which will enable him/her to be well prepared for primary and higher education and to fit appropriately into his/her society. Directly linked to ECE is the QECE.

Despite a growing consensus on the centrality of quality in ECE education, its principal meaning remains universally undefined, possibly due to different explanations and meanings given to it throughout history from culture to culture; according to the goals and values of each society (Ankomah et al., 2005; Cleveland et al., 2006; Ishimine, Tayler \& Thorpe, 2009).

This issue regarding definition and differences in terms of cultural values make it difficult to compare the quality of ECE provision across nations; as there may be cultural variations regarding what is considered important and of quality (Mooney et al., 2003). However, no matter how quality is defined nor the perspective from which it is defined, the literature clearly shows that it is of great importance to the provision of ECE (e.g., Sylva et al., 2004; Schweinhart, Barnes and Weikart, 2005; Lowenstein, 2011).

\subsection{Perspectives on Quality Education}

UNESCO conceives quality education as that which meets basic learning needs. including literacy, numeracy, problem-solving, which will enable individuals to survive, develop their full potential, live and work with pride, improve the quality of their lives and make informed decisions (UNESCO, 2005). The definition of a learning need can differ between countries and cultures and over time. For UNESCO, therefore, quality education is measured in consonance with the goals and objectives spelt out in a particular cultural context (Tikly \& Barrett, 2010).

In Ghana specifically, quality education (including ECE) is conceptualised as a continuum of input, process, and outcome (Ankomah et al., 2005). The inputs comprise educational personnel, pedagogical and content knowledge, educational facilities, and finance. A quality educational outcome is one in which children can achieve success in their examinations and which improves their 
participation in social and political activities and their health habits. In determining quality ECE, considerations such as curricula, teachers, pedagogy, materials, and infrastructure/environment are generally identified as the building blocks.

\subsection{How Interaction brings about QECE}

From the foregoing discourse, factors such as availability and accessibility of TLMs and play items, the nature of the ECE environment, and the quality of the teacher all contribute to quality ECE provision. Nevertheless, key in bringing about QECE is how interaction features in each of these blocks.

\subsubsection{How the Teacher's Training with Interaction can bring about QECE}

With respect to teacher qualification, the significance of teachers' training and qualifications in determining the quality of classroom interactions cannot be underestimated. Research findings suggest that specific training improves the quality of teacher-learner interaction (Hamre \& Pianta, 20021, Domitrovich et al., 2008; Pianta et al., 2008; Hamre et al., 2012). For example, research shows that teachers who have knowledge of child development and early childhood practices through their professional training are able to facilitate better interaction (be it teacher-learner or learner-content relationship), use praise and encouraging words, are responsive to their children's needs and support their interests (Howes, James \& Ritchie, 2003; Lerkkanen et al., 2012). What is worthy of note is that it is not just the training of the teacher that brings about the quality but how the teacher, through training, is able to interact with learners, create opportunities for interaction to prevail among learners and between learners in their environment and encourage praise, among other things, is what brings about the quality of early childhood education provision.

\subsubsection{How the Teacher's Pedagogy with Interaction can bring about QECE}

The pedagogy teachers adopt including the use of TLMs is another block that ensures QECE and the researcher agree with Elliott (2006) that, although the professional qualifications of teachers are important, more important still are teachers' abilities to adopt appropriate pedagogical strategies (e.g., praising, guiding, and group work), use appropriate TLMs and stimulate an interactive environment, abilities which emerge through professional training. Interaction is most likely to be improved if the teacher is professionally trained in ECE and is able to adopt developmentally appropriate strategies, such as involving learners, providing feedback to learners, and engaging learners in small group and whole-class activities during a lesson delivery (e.g., La Paro, Pianta \& Stuhlman, 2004; O'Connor, 2010). In a classroom in which the teacher involves the learners in the lesson delivery and the learners are free to ask questions, interaction is fostered and conflict is reduced among learners (Mantzicopoulos, 2005). The reverse is also true in an instance where whole class activity is always used and teaching strategies don't suit individual learning needs. 


\subsubsection{Pupil-Teacher ratio and how Interaction can be featured to bring about QECE}

The number of learners that an ECE teacher is supposed to handle also affects the quality of the interaction he/she will have with learners in the classroom and in the school. Research has shown that the quality of interaction between teachers and learners tends to be higher in classrooms in which the teacher-learner ratio is lower (NICHD ECCRN, 2002; 2000; Goelman et al., 2006; Al-Thani, 2008; White, 2013). This is possible because there will be more opportunities in such classrooms for teachers to engage children in activities and to provide time for them to be involved in activities that support their cognitive, social, and emotional development. Burchinal et al. (2000) have indicated that interaction is of poor quality where class sizes are large. Teachers who are responsible for relatively larger numbers of learners are known to be harsher and less responsive to the needs of their learners (Carl, 2007, citing Whitebook et al., 1990; Belsky, 1984, cited in Kisitu, 2008). Such teachers are also more likely to employ restrictive measures in controlling learners' behaviour (Kontos \& Fiene, 1986, cited in Carl, 2007). Equally, this kind of ratio is associated with the implementation of inappropriate teaching practices, the use of teacher-centred pedagogy, and more teacher-controlled routine activities in the classroom.

This implies that, for a teacher to be relaxed in the measures he/she takes to control the class and to be able to respond appropriately to the needs of the learners, the pupil-teacher ratio should be lower (i.e., when the teacher can conveniently manage the children in the class and the classroom activities, including prompt attendance to children's needs).

\subsubsection{How Interaction can be featured in the Environment to Bring about QECE}

Another avenue interaction can be featured to ensure QECE is through the environment in which ECE is carried out. The physical environment of an ECE setting (including the size of the classroom, the type of furniture and the general arrangement of the classroom as well as the features of outdoor settings) provide opportunities for learners to explore their environment and learn (NAEYC, 1991; Rentzou, 2014; Oppong Frimpong, 2019). They are crucial in ensuring effective interaction and for that matter QECE provision (NAEYC, 1991; UNESCO, 2005).

This proposes that the environment should be carefully arranged to, for example, create space for a range of activities, and Kisitu (2008) agrees with this, arguing that the amount of space created has a ripple effect on the extent to which children will be able to move and interact freely and the amount of learning they will accomplish. A well-arranged classroom (e.g. where children can freely move, where well-labelled learning centres are created) helps children to develop appropriate peer interactions, independent learning, and exploratory behaviour (NAEYC, 1991; Chapman, 2005, cited in Kisitu, 2008), improves teacher-learner interaction (Moore, 1986 cited in Carl, 2007), and is associated with decreased aggressive behaviour (Moore, 1987). 
Figure 3 presents the Conceptual Quality Early Childhood Education Framework (CQECEF). The figure shows the conceptual position of QECE, the building blocks or factors for QECE, and the role of quality interaction in leading to QECE provision. The main conceptual factors/blocks are teachers and the nature of the environment in which a particular ECE is provided. With respect to the teachers, emphasis is laid on their professional training and CPD, the pedagogy and TLMs they use, and the pupil-teacher ratio. The nature of the environment includes the availability of TLMs and play items and the nature of the physical infrastructure. All these factors or building blocks are linked with each other. At the end of the day, they all become useful or beneficial to achieve QECE based on how interaction is featured. In other words, the quality of the interaction in each of these factors is what leads to QECE provision. 


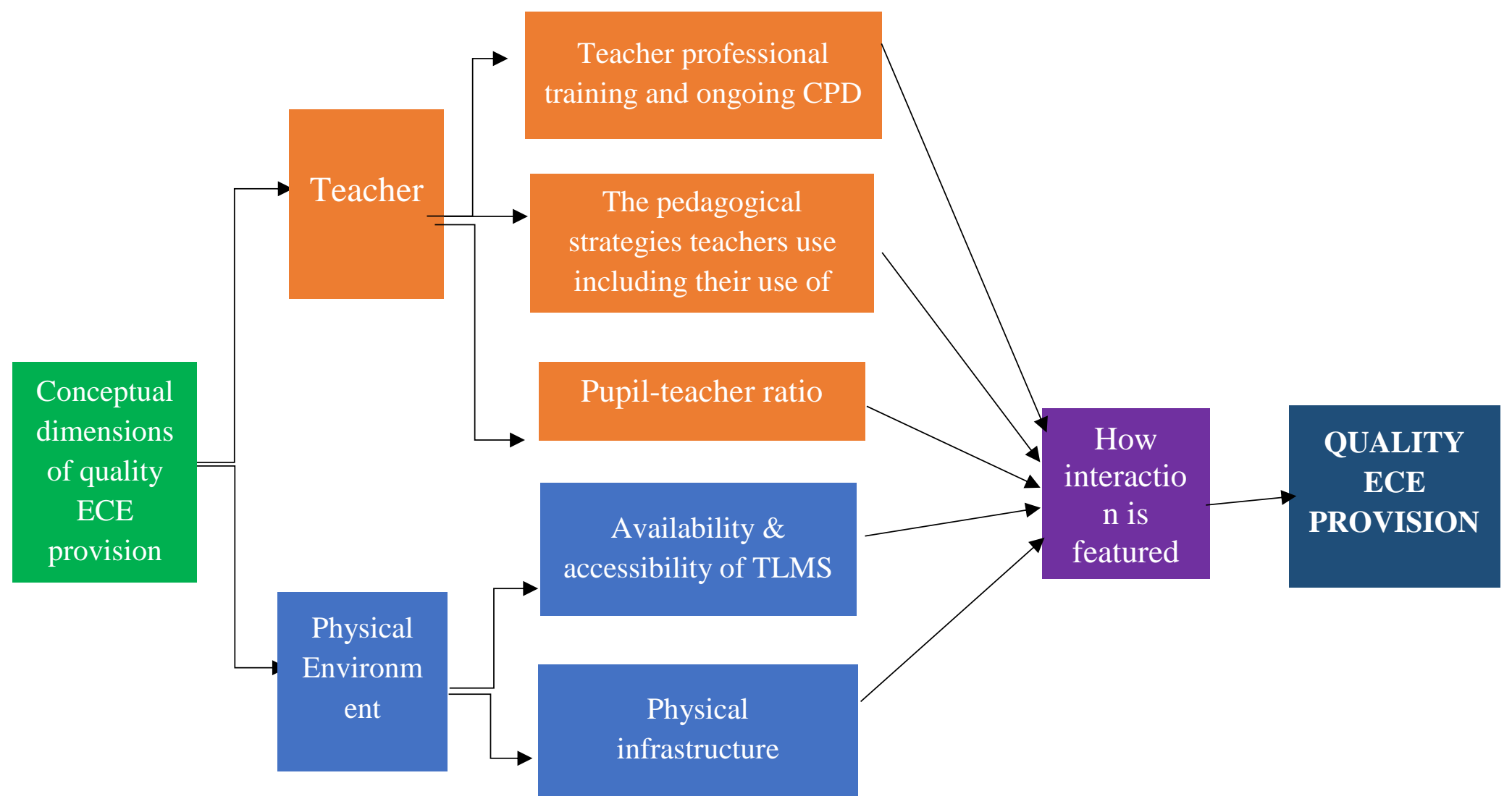

Figure 3: Conceptual Quality ECE Framework 


\section{Conclusion}

The discussion of interaction points out its indispensable role in QECE provision. The researcher posits it to be the most important ingredient in QECE provision as it is the means by which an early childhood centre functions on a daily basis. This is because the quality of interaction and instruction young children have in ECE schools can make or unmake their later lives. If TLMs are available but learners cannot have contact with them, learning will not take place. Similarly, if teachers fail to interact with their learners and involve them in their teaching and learning, instruction becomes teacher-centred, which may not be fully beneficial to learners. Consequently, the extent and quality of contact between teachers and learners, and learners and TLMs in an early childhood centre contributes significantly to the quality of its ECE delivery.

\section{Recommendations}

Undoubtedly, the article has been able to argue in favour of positive interaction for quality early childhood education provision. The aspiration of every nation particularly the developing ones, Ghana inclusive, is to turn out learners who have experienced quality early years education. The preparations Ghana has put in place with a view at achieving quality education particularly in the early years, including the introduction of the new curriculum, cannot be underestimated. Nevertheless, what can potentially help to achieve the aspirations of the school is to anchor the provision of the early years' education on interaction. Subsequently, the following recommendations are made.

The training of teachers for the early years should focus on how they can actively involve learners in their teaching and learning process. The content of the training of the teachers should focus mainly on the characteristics of the learner and how he or she learns. The fact that learning is fostered in the early years when learners are actively involved in the teaching and learning process. This should be translated by the teachers when they finally get to the classrooms after their training.

Active learner involvement should be what should drive all the activities of the teacher in the ECE classroom. Thus, even if the teacher is confronted with a higher teacher-learner ratio, with this idea in mind, the said teacher should resort to doing group activities and finding other innovative ways of actively involving their learners in all they do. Periodic use of group activities can also ensure effective utilization of teaching-learning resources especially where they are shot in supply.

Classrooms can be arranged to create space. Teachers should therefore try to vary, arrange, and re-range their classrooms in a manner that will create enough space to ensure learner active involvement in the classroom activities. Interaction should be a whole day whole school activity. This 
means that it should not be done only for a particular activity and at a particular place like the classroom. Interaction should extend beyond the classroom to include outdoor activities and whatever the children do throughout the school day.

\section{REFERENCES}

Al-Thani, T. J., (2008). Early years education in Qatar: a comparative study of its nature, provision, and quality in national and international pre-school settings. Unpublished PhD thesis submitted to the Durham University.

Ankomah, Y. A., Koomson, J A., Bosu, R. S. \& Oduro, G. K. T., (2005). A review on the concept of quality in education: Perspectives from Ghana: EdQual Working Paper No.1 (Ghana, EdQual).

Burchinal, M.R., Roberts, J.E., Riggins, R., Zeisel, S.A., Neebe, E. \& Bryant, D. (2000). Relating quality of centre-based child care to early cognitive and language development longitudinally. Child Development, 71 (2), 338-357. https://doi.org/10.1111/1467$\underline{8624.00149}$

Cadima, J., Leal, T. \& Burchinal, M. (2010). The quality of teacher-student interactions: Associations with first graders' academic and behavioural outcomes. Journal of School Psychology 48, 457-482. https://doi.org/10.1016/j.jsp.2010.09.001

Carl, B. (2007). Child Caregiver Interaction Scale. Unpublished Dissertation Submitted to the School of Graduate Studies and Research in Partial Fulfilment of the Requirements for the Degree Doctor of Philosophy in Indiana University of Pennsylvania. Unpublished PhD thesis submitted to University of Pennsylvania

Chapman, A., 2005). Children will love to learn in a fun classroom: Early years Educator, 7, (6), 17-31. https://doi.org/10.12968/eyed.2005.7.6.19650

Cleveland, G., Corter, C., Pelletier, J., Colley, S., Bertrand, J. \& Jamieson, J., (2006). Early childhood learning and development in child care, kindergarten and family support programs. Toronto, ON: Atkinson Centre at OISE/UT.

Cobbold, C. (2006). Attracting and retaining rural teachers in Ghana: the premise and promise of a district sponsorship scheme. Journal of Education for Teaching, 32, (4), 453-469. https://doi.org/10.1080/02607470600982142

Domitrovich, C. E., Bradshaw, C. P., Poduska, J., Hoagwood, K., Buckley, J., Olin, S., Et al. (2008). Maximizing the implementation quality of evidence-based preventive interventions 
in schools: A conceptual framework. Advances in School Mental Health Promotion, 1, 6-28. https://doi.org/10.1080/1754730X.2008.9715730

Domitrovich, C. E., Gest, S., Gill, S., Bierman, K. L., Welsh, J. A., \& Jones, D., (2009). Fostering High-Quality Teaching with an enriched curriculum and professional development support: The Head Start REDI Program. American Educational Research Journal, 46 (2), 567-597. https://doi.org/10.3102/0002831208328089

Early, D.M., Maxwell, K.L., Burchinal, M., Alva, S., Bender, R., Bryant, D., K., Clifford R. M., Ebanks C., Griffin J. A., Henry G. T., Howes C., Iriondo-Perez J., Jeon H., Mashburn A. J., Peisner-Feinberg E., Pianta R. C., Vandergrift N., \& Zill N. (2007). Teachers' education, classroom quality, and young children's academic skills: Results from seven studies of preschool programs. Child Development, 78, 558-580. https://doi.org/10.1111/j.1467$\underline{8624.2007 .01014 . \mathrm{x}}$

Elliott, A. (2006). "Early Childhood Education: Pathways to quality and equity for all children", Australian Education Review, Vol. 50, Australian Council for Educational Research.

Gilliam, W. S., (2009). Preschool Promises: An Introduction, Commentary, and Charge. Psychological Science in the Public Interest 10 (2), 1-5. https://doi.org/10.1177/1529100610387083

Goelman, H., Forer, B., Kershaw, P., Doherty, G., Lero, D., \& Lagrange, A. (2006). Towards a predictive model of quality in Canadian child care centres. Early Childhood Research Quarterly, 21, 280-295. https://doi.org/10.1016/j.ecresq.2006.07.005

Hamre, B. K., \& Pianta, R. C. (2001). Early teacher-child relationships and the trajectory of children's school outcomes through eighth grade. Child Development, 72, 625-638. https://doi.org/10.1111/1467-8624.00301

Hamre, B. K., \& Pianta, R. C., (2007). Learning opportunities in preschool and early elementary classroom. In R. C., Pianta, M. J., Cox., and K. L. Snow, eds., School readiness and the transition to kindergarten in the era of accountability, 49-83. Baltimore, MD: Paul H. Brookes.

Hamre, B. K., Pianta, R. C., Burchinal, M., Field, S et al. (2012). A course on effective teacherchild interactions: Effects on teacher beliefs, knowledge, and observed practice. American Educational Research Journal 49, (1), 88-123. https://doi.org/10.3102/0002831211434596 Howes, C., J. James \& S. Ritchie (2003), "Pathways to effective teaching”, Early Childhood Research Quarterly, 18, 104-120. https://doi.org/10.1016/S0885-2006(03)00008-5 
Ishimine, K., Tayler, C., \& Thorpe, K., (2009): Accounting for quality in Australian childcare: a dilemma for policymakers, Journal of Education Policy, 24 (6), 717-732. https://doi.org/10.1080/02680930903207695

Kisitu, W. (2008). Early childhood care and education in Uganda: The challenges and possibilities for achieving quality and accessible provision. A thesis Submitted to the University of Edinburgh in fulfilment of the requirements for the degree of Doctor of Philosophy. Unpublished PhD Thesis University of Edinburgh, UK.

La Paro, K. M., Pianta, R. C., \& Stuhlman, M. (2004). The Classroom Assessment Scoring System: Findings from the pre-kindergarten year. The Elementary School Journal, 104 (5), 409-426. https://doi.org/10.1086/499760

Lerkkanen, M., Kikas, E., Pakarinen, E., Trossmann, K., Poikkeus, A., Rasku-Puttonen, H., Et Al., (2012). A Validation of the Early Childhood Classroom Observation Measure in Finnish and Estonian Kindergartens, Early Education and Development, 23 (3), 323-350. https://doi.org/10.1080/10409289.2010.527222

Lowenstein A. E., (2011). Early care and education as Educational Panacea: What do we really know about its effectiveness? Educational Policy, 25 (1), 92-114. https://doi.org/10.1177/0895904810387790

Mantzicopoulos, P. (2005). Conflictual relationships between kindergarten children and their teachers: Associations with child and classroom context variables. Journal of School Psychology, 43, 425-442. https://doi.org/10.1016/j.jsp.2005.09.004

Ministry of Women and Children's Affairs, (2004). Early Childhood Care and Development Policy, Ghana: Republic of Ghana.

Mooney, A. (2007). The effectiveness of quality improvement programmes for early childhood education and childcare. Report prepared for Thomas Coram Institute, University of London.

Mooney, A., C. Cameron, M. Candappa, S. Mcquail, P. Moss, \& Petrie, P. (2003). Early years and childcare international evidence project: Quality. London: Sure Start.

Mooney, C. G., (2000). Theories of childhood: An introduction to Dewey, Montessori, Erikson, Piaget, and Vygotsky., MN: Redleaf Press. St. Paul

Moore, G. T., (1987). The Physical Environment and Cognitive Development in Child Care Centres. In Weinstein, C.S., and David, T.G., (Eds.) Spaces for Children: The Built Environment and Child Development. New York: Plenum. https://doi.org/10.1007/978-1$\underline{4684-5227-3 \_3}$ 
Moore, M. G. (1989). Editorial: Three types of interaction. American Journal of Distance

Education, 3 (2), 1-7. https://doi.org/10.1080/08923648909526674

https://doi.org/10.1080/08923648909526659

https://doi.org/10.1080/08923648909526645

Murphy, D., Casey, D., \& Fraser, J. (2007). Talk about walkabout: evaluation of a flexible learning initiative. In P. Tsang, R. Kwan \& R. Fox (Eds.), Enhancing Learning through Technology (pp. 11-26). London: World Scientific Publishing Co. Pte. Ltd. https://doi.org/10.1142/9789812772725_0002

National Association for The Education of Young Children. (NAEYC) (1991). Accreditation criteria and procedures of the National Academy of Early Childhood Programs (Rev. ed.). Washington, DC: NAEYC

Ngware, M. W., Oketch, M., \& Mutisya, M. (2014). Does teaching style explain differences in learner achievement in low and high performing schools in Kenya. International Journal of Educational Development, 36, 3-12. https://doi.org/10.1016/j.ijedudev.2014.01.004

NICHD ECCRN. (2000). The relation of child care to cognitive and language development. Child Development, 71, 960-980. https://doi.org/10.1111/1467-8624.00202

NICHD ECCRN. (2002). Early child care and children's development prior to school entry: Results from the NICHD Study of Early Child Care. American Educational Research Journal, 39, 133-164. https://doi.org/10.3102/00028312039001133

O'connor, E. (2010). Teacher-child relationships as dynamic systems. Journal of School Psychology 48, 187-218. https://doi.org/10.1016/j.jsp.2010.01.001

Oppong Frimpong, S. (2017). An investigation into the quality of interaction in early childhood education in Ghana: A constructivist perspective. A thesis submitted in fulfilment of the requirements for the degree of Doctor of Philosophy, School of Education, College of Arts and Social Sciences, University of Aberdeen, UK. Unpublished PhD Thesis.

Oppong Frimpong, S. (2019). The Classroom Physical Environment as a "Third Teacher" For an Early Childhood Education Provision in the Ga-West Municipality of Ghana. PEOPLE: International Journal of Social Sciences, 4 (3), 1339-1360. https://doi.org/10.20319/pijss.2019.43.13391360

Pianta, R. C., Barnett, W. S., Burchinal, M., \& Thornburg, K. R., (2009). The effects of preschool education: What we know, how public policy is or is not aligned with the evidence base, and what we need to know. Psychological Science in the Public Interest, 10 (2), 49-88. https://doi.org/10.1177/1529100610381908 
Pianta, R. C., La Paro, K. M., \& Hamre, B. (2008). The classroom assessment scoring system, PreK Version. Baltimore, MD: Paul

Rentzou, K. (2014). The quality of the physical environment in private and public infant/toddler and preschool Greek day-care programmes. Early Child Development and Care. 184 (12), 1861-1883. https://doi.org/10.1080/03004430.2014.891991

Schweinhart, L. J., Barnes, H. V., \& Weikart, D. P., (2005). Lifetime effects: The High/Scope Perry Preschool Study through age 40. Ypsilanti, MI: High/Scope Press.

Sylva, K., Melhuish, E., Sammons, P., Siraj-Blatchford, I., \& Taggart, B., (2011). Pre-school quality and educational outcomes at age 11: Low quality has little benefit. Journal of Early Childhood Research, 9 (2), 109-124. https://doi.org/10.1177/1476718X10387900

Sylva, K., Melhuish, E., Sammons, P., Siraj-Blatchford, I., \& Taggart, B., (2004). The Effective Provision of Pre-School Education (EPPE) Project: Technical paper 12 - The final report. DfES/Institute of Education, University of London.

Tikly, L. \& Barrett, A. M. (2010, November). A framework for education quality. EdQual Policy Brief No. 10. (Bristol, EdQual).

Torrente, C. et al. (2015). Improving the quality of school interactions and student well-being: Impacts of one year of a school-based program in the Democratic Republic of the Congo. Journal on Education in Emergencies, 1 (1), 48-91.

UNESCO (2010). ECCE regional Report-Africa. Senegal: Published by the Regional Bureau for Education in Africa (BREDA)

White, K. M. (2013). Associations Between Teacher-Child Relationships and Children's Writing in Kindergarten and First Grade. Early Childhood Research Quarterly, 28, 166- 176. https://doi.org/10.1016/j.ecresq.2012.05.004 